\title{
The Effect of Prophylactic Topical Brimonidine on Intraocular Pressure After Nd: YAG Laser Posterior Capsulotomy
}

\author{
Ümit Çalli,, Berkay Akmaz,, Taha Ayyıldız, ${ }^{1}$ Ayşe Yeşim Oral, ${ }^{1}$ \\ Muhammed Nurullah Bulut, ${ }^{1}$ Yusuf Özertürk'
}

\begin{abstract}
'Department of Ophthalmology, Kartal Dr. Lütfi Kırdar Training and Research Hospital, İstanbul, Turkey

2Department of Ophthalmology,

Katip Çelebi University Atatürk

Training and Research Hospital, İzmir, Turkey

Submitted: 21.03.2015 Accepted: 12.06.2016

Correspondence: Ümit Çallı, Şemsi Denizer Caddesi, E-5 Karayolu Cevizli Mevki, 34890 Kartal, İstanbul, Turkey

E-mail: umitcalli52@hotmail.com
\end{abstract}

(

Keywords: Brimonidine; intraocular pressure; IOP; YAG laser.

\begin{abstract}
Objective: The aim of this study was to evaluate the effect of topical brimonidine on intraocular pressure (IOP) after Neodymium: yttrium aluminum garnet laser posterior capsulotomy.

Methods: Forty patients (40 eyes) who underwent posterior capsulotomy were included in the study. Patients were divided into Groups A and B. Topical brimonidine was applied I hour prior to and right after laser procedure in Group A. Group B was assessed as control group. Intraocular pressures of the patients were measured using aplanation tonometry (Goldmann) before, I hour, I day and I week after laser procedures.

Results: Mean IOP at baseline was $14.7 \pm 3 \mathrm{mmHg}$ in Group A and $14.6 \pm 3.9 \mathrm{mmHg}$ in Group B. In Group A, IOP decreased to $12.7 \pm 3.3 \mathrm{mmHg}$ after I hour, $13.7 \pm 2.3 \mathrm{mmHg}$ after I day, and $14.2 \pm 2.3 \mathrm{mmHg}$ after I week. The values were measured respectively as $15.1 \pm 2.9$ $\mathrm{mmHg}, 14.9 \pm 2.1 \mathrm{mmHg}$, and $14.5 \pm 2 \mathrm{mmHg}$ in Group B. IOP had decreased significantly at I hour and at I day after laser treatment when compared with baseline in Group A; no significant difference was found after I week. No statistically significant difference was found during follow-up period compared to baseline in Group B.
\end{abstract}

Conclusion: Use of brimonidine was demonstrated to prevent rise in IOP. In addition, there was no significant IOP increase as result of fewer shots and low energy laser treatment.

\section{INTRODUCTION}

Despite technical advances in cataract surgery, the use of new intra-ocular lenses (IOL) with sharp edge design, and new biomaterials, the most common complication of cataract surgery is still posterior capsule opacification (PCO). ${ }^{\left[{ }^{1-4}\right]}$ Neodymium: yttrium aluminum garnet (Nd: YAG) laser posterior capsulotomy has been used successfully to treat $P C O .^{[5]}$ Various complications such as retinal detachment, temporary increase in intra-ocular pressure (IOP), IOL damage, uveitis, and cystoid macular edema may occur. ${ }^{[6-8]}$
Increase in IOP manifests itself particularly within the first 3 hours, and though it usually heals without sequelae, it may cause loss of vision or visual field, especially in patients with glaucoma. ${ }^{[9]}$ Topical apraclonidine $0.5 \%-1 \%$, brimonidine $0.2 \%$, timolol maleate $0.5 \%$, and combinations of brimonidine-timolol or dorsolamid-timolol can be used to prevent increase in IOP, and generally any increase in IOP after laser procedure can be brought under control. ${ }^{[10-13]}$

The aim of the present study was to analyze the effect of topical brimonidine use on IOP and changes in IOP in patients who did not receive prophylaxis drug. 


\section{MATERIAL AND METHODS}

The study included 40 eyes of 40 patients whose pre-laser $I O P$ value was less than $18 \mathrm{mmHg}$ as measured with Goldmann applanation tonometry, and on whom posterior capsulotomy was performed due to PCO. Written, informed consent was obtained from patients after having informed them about all possible complications prior to the procedure. This study was approved by the Hospital Ethics Board (March II, 2014 Etik Kur.895/3307//009/240). Patients were divided into 2 groups: Group $A$ and Group B. Both groups were comprised of 12 female and 8 male patients; mean age in Group A was $60.8 \pm 12.4$ years, and mean age in Group B was 59.9 13.2 years. Pupil dilation in all patients was ensured with application of tropicamide $0.5 \%$ (Tropamid) 30 minutes prior to the laser procedure. Five minutes before the procedure, topical anesthesia was obtained with proparacaine drop (Alcaine). Topical brimonidine (Alphagan P) was applied I hour prior to laser and right after laser to patients in Group $A$; as control group, no drug was applied to the 20 patients in Group B. Prelaser, first hour post-laser, first day post-laser, and first week IOP values of patients were calculated with applanation tonometry. Nepafenac drops (Nevanac) were applied to all patients 3 times a day for I week. With the help of capsulotomy lens, capsulotomy was performed on optic axis area in a (+) shape with low power, starting at $1.2 \mathrm{~mJ}$ Mean power was $15.3 \pm 3.6 \mathrm{~mJ}$ in Group A and $15.4 \pm 3.6$ $\mathrm{mJ}$ in Group B; mean number of shots in Group A was

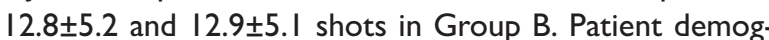
raphics before laser procedure are provided in Table I. All values were evaluated statistically using SPSS software (Statistical Package for Social Sciences version 22.0; SPSS Inc., Chicago, IL, USA).

\section{RESULTS}

Mean pre-laser IOP value was $14.7 \pm 3 \mathrm{mmHg}$ in Group A and $14.6 \pm 3.9 \mathrm{mmHg}$ in Group B. Initially, there was no statistically significant difference between the 2 groups (Mann-Whitney $U$ test; $p>0.05$ ). Mean post-laser IOP measurements at first hour, first day, and at first week postprocedure were $12.7 \pm 3.3 \mathrm{mmHg}, 13.7 \pm 2.3 \mathrm{mmHg}$, and $14.2 \pm 2.3 \mathrm{mmHg}$, respectively, in Group A, and $15.1 \pm 2.9$ $\mathrm{mmHg}, 14.9 \pm 2.1 \mathrm{mmHg}$, and $14.5 \pm 2 \mathrm{mmHg}$ in Group B (Figure I). While first hour and first day IOP values were statistically lower in Group A when compared to Group B (Mann-Whitney $U$ test; $p<0.05)$, there was no statistically significant difference between first week values (Mann-Whitney $U$ test; $p>0.05$ ). When the groups were evaluated separately, a statistically significant decrease was seen at first hour and on first day in Group A (Wilcoxon signed ranks test; $p<0.05$ ), and a statistically insignificant IOP increase was recorded at first hour and first day in
Group B (Wilcoxon signed ranks test; $p>0.05$ ). A statistically significant difference in first week IOP values in both groups was not found when compared to pre-laser values (Wilcoxon signed ranks test; $p>0.05$ ). While there was no increase in post-laser IOP values of any patient in Group $A$, first hour IOP values showed an increase in 8 patients in Group B while 12 remained the same. In 6 patients in Group B it was observed that first day IOP values decreased to pre-laser values or lower, and it was detected that IOP values decreased to pre-laser values or lower in all patients at first week measurement.

\section{DISCUSSION}

PCO can be successfully treated with Nd: YAG laser posterior capsulotomy and a satisfactory increase in visual acuity can be ensured. IOP increase after Nd: YAG laser is a complication reported at various intervals. ${ }^{\left[{ }^{[1]}\right]}$ Studies in the literature indicate the efficiency of various anti-glaucomatous agents in the control of IOP. It was reported in a study by Ateş et al. that they provided early IOP control with I week of brimonidine use after prophylactic apraclonidine and that they found first hour and first day IOP values in the control group significantly high. ${ }^{\left[{ }^{[5]}\right.}$ Similarly, Singhal et al. stated that with prophylactic use of brimonidine they saw a significant decrease in IOP values when compared to the control group. ${ }^{[6]}$ There are also studies in the literature reporting that a significant change was not detected in IOP values after laser capsulotomy. YazıcI et al. stated that they did not detect a significant change in post-laser IOP values with regard to pre-laser values. ${ }^{[17]}$ In another study, Özkurt et al. indicated that they did not detect a significant increase in first day, first month and third month IOP values after YAG laser capsulotomy compared to pre-laser values. ${ }^{[18]}$ In the present study, there was no significant increase in the group where brimonidine was not used; however, in the group where prophylactic brimonidine was applied, post-laser first hour and first day $I O P$ values were statistically significantly lower compared to pre-laser values and control group values. The reason for these varied results may be total power used in YAG

Table I. Comparison of patient demographics

\begin{tabular}{lccc}
\hline & Group A & Group B & p \\
\hline $\begin{array}{l}\text { Gender } \\
\text { Male }\end{array}$ & 12 & 12 & $>0.05$ \\
$\quad$ Female & 8 & 8 & \\
Age60.8 & 59.9 & $>0.05$ & \\
Total power & 15.3 & 15.4 & $>0.05$ \\
Number of shots & 12.8 & 12.9 & $>0.05$ \\
Intraocular pressure & 14.7 & 14.6 & $>0.05$ \\
\hline
\end{tabular}




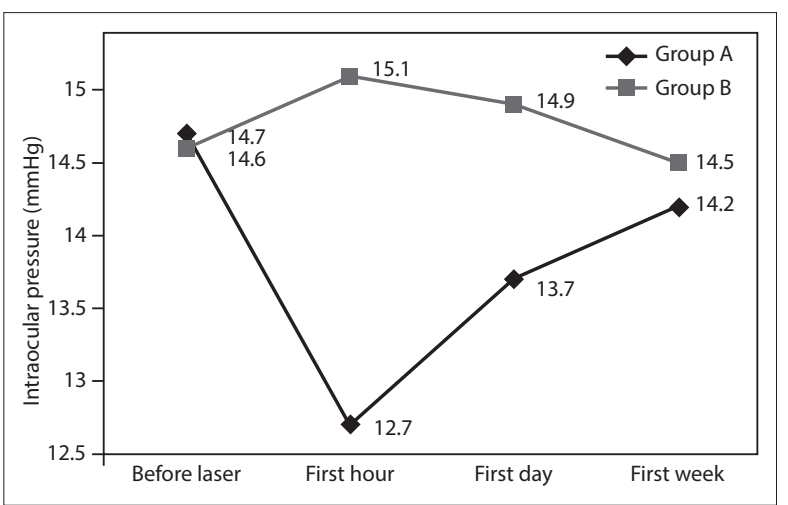

Figure 1. Comparison of IOP changes by group.

laser and difference in the number of shots. There are articles in the literature reporting different results regarding the effect on IOP increase of the number of shots and total power used. Kaur et al. reported that they achieved significant IOP control with prophylactic apraclonidine compared to control group and that they did not find a relationship between IOP increase and total power. ${ }^{[19]}$ In another article, Cumurcu and Etikan stated that IOP increase had correlation to the number of shots and total power used. ${ }^{[20]}$ In the present study, use of prophylactic brimonidine provided a significant decrease with regard to pre-laser IOP values, and low power and few shots were used. There was no significant increase in IOP in patients with normal pre-laser IOP values.

In conclusion, YAG laser posterior capsulotomy can be used as a safe method to treat PCO. In the present study, along with not observing a significant IOP increase in the group where prophylactic brimonidine was not used, efficient IOP control was provided in the group where brimonidine was used. The number of shots applied during laser procedure, total power used, and the level of postprocedure inflammation suppressed with an agent can be important factors affecting IOP changes after YAG laser. Additional studies are needed to evaluate the effects of these factors on IOP changes after YAG laser posterior capsulotomy.

\section{REFERENCES}

1. Apple DJ, Solomon KD, Tetz MR, Assia EI, Holland EY, Legler UF, et al. Posterior capsule opacification. Surv Ophthalmol 1992;37:73116.

2. Apple DJ, Peng Q, Visessook N, Werner L, Pandey SK, Escobar-Gomez M, et al. Surgical prevention of posterior capsule opacification. Part 1: Progress in eliminating this complication of cataract surgery. J Cataract Refract Surg 2000;26:180-7.

3. Peng Q, Visessook N, Apple DJ, Pandey SK, Werner L, Escobar-Gomez M, et al. Surgical prevention of posterior capsule opacification. Part 3: Intraocular lens optic barrier effect as a second line of defense. J Cataract Refract Surg 2000;26:198-213.

4. Apple DJ. Influence of intraocular lens material and design on post- operative intracapsular cellular reactivity. Trans Am Ophthalmol Soc 2000;98:257-83.

5. Holweger RR, Marefat B. Intraocular pressure change after neodymium:YAG capsulotomy. J Cataract Refract Surg 1997;23:115-21.

6. Polak M, Zarnowski T, Zagórski Z. Results of Nd:YAG laser capsulotomy in posterior capsule opacification. Ann Univ Mariae Curie Sklodowska Med 2002;57:357-63.

7. Steinert RF, Puliafito CA, Kumar SR, Dudak SD, Patel S. Cystoid macular edema, retinal detachment, and glaucoma after Nd:YAG laser posterior capsulotomy. Am J Ophthalmol 1991;112:373-80.

8. Billotte C, Berdeaux G. Adverse clinical consequences of neodymium:YAG laser treatment of posterior capsule opacification. J Cataract Refract Surg 2004;30:2064-71.

9. Lin JC, Katz LJ, Spaeth GL, Klancnik JM Jr. Intraocular pressure control after Nd:YAG laser posterior capsulotomy in eyes with glaucoma. Br J Ophthalmol 2008;92:337-9.

10. Cai JP, Cheng JW, Wei RL, Ma XY, Jiang F, Zhu H, et al. Prophylactic use of timolol maleate to prevent intraocular pressure elevation after Nd-YAG laser posterior capsulotomy. Int Ophthalmol 2008;28:1922.

11. Gartaganis SP1, Mela EK, Katsimpris JM, Petropoulos JK, Karamanos NK, Koliopoulos JX. Use of topical brimonidine to prevent intraocular pressure elevations following Nd:YAG-laser posterior capsulotomy. Ophthalmic Surg Lasers 1999;30:647-52.

12. Pollack IP, Brown RH, Crandall AS, Robin AL, Stewart RH, White GL. Prevention of the rise in intraocular pressure following neodymium-YAG posterior capsulotomy using topical $1 \%$ apraclonidine. Arch Ophthalmol 1988;106:754-7.

13. Öner V, Alakuş MF, Taş M, Türkyılmaz K, Işcan Y. Fixed combination brimonidine-timolol versus brimonidine for treatment of intraocular pressure elevation after neodymium:YAG laser posterior capsulotomy. J Ocul Pharmacol Ther 2012;28:576-80.

14. Awan AA, Kazmi SH, Bukhari SA. Intraocular pressure changes after Nd-YAG laser capsulotomy. J Ayub Med Coll Abbottabad 2001;13:3-4.

15. Ateş Z, Ayata A, Sevim S, Türkyılmaz K. Efficiency of Brimonidine 0.2\%on Intraocular Pressure Elevation After Nd:Yag Laser Posterior Capsulotomy. Glokom-Katarakt 2009;2:112-4.

16. Singhal D, Desai R, Desai S, Shastri M, Saxena D. Use of topical brimonidine to prevent intraocular pressure elevations following Nd: YAG-laser posterior capsulotomy. J Pharmacol Pharmacother 2011;2:104-6.

17. Yazıcı AT, Bozkurt E, Yıldırım Y, Kara N, Demirok A, Yılmaz ÖF. Effect of Nd:Yag Laser Posterior Capsulotomy on Visual Acuity, Intraocular Pressure, and Macular Thickness. Glokom-Katarakt 2010;5:151-4.

18. Ozkurt YB, Sengör T, Evciman T, Haboğlu M. Refraction, intraocular pressure and anterior chamber depth changes after Nd:YAG laser treatment for posterior capsular opacification in pseudophakic eyes. Clin Exp Optom 2009;92:412-5.

19. Kaur M, Singh AA, Kailwoo SK. Apraclonidine $1 \%$ to prevent post $\mathrm{Nd}$ : YAG laser capsulotomy rise of intraocular pressure. JARBS 2012;4;237-42.

20. Cumurcu T, Etikan I. Correlation of Total Energy, Pulse Energy and Pulse Number with intraocular pressure rise after YAG Laser Posterior Capsulotomy. Erciyes Tip Derg 2006;28:7-12. 


\section{Profilaktik Topikal Brimonidine Kullanılanımının Nd: YAG Laser Arka Kapsülotomi Sonrası Göz İçi Basınç Değişimlerine Etkisi}

Amaç: Neodymium: yttrium aluminum garnet (Nd: YAG) laser arka kapsülotomi yapılan hastalarda profilaktik topikal brimonidine kulanımının göz içi basıncı (GiB) üzerine etkisini değerlendirmek.

Gereç ve Yöntem: Arka kapsülotomi yapılan 40 hastanın 40 gözü çalışmaya dahil edildi. Hastalar A ve B olarak 2 gruba ayrıldı. A grubundaki 20 hastaya laser öncesi I. saat ve laserden hemen sonra topikal brimonidine kullanılırken, B grubundaki 20 hasta kontrol grubu olarak belirlendi. Hastaların laser öncesi, laser sonrası I. saat, I. gün ve I. hafta GiB değerleri aplanasyon tonometri (Goldmann) ile ölçüldü.

Bulgular: Laser tedavisi öncesi ortalama GiB değeri A grubunda $14.7 \pm 3 \mathrm{mmHg}$, B grubunda $14.6 \pm 3.9 \mathrm{mmHg}$ idi. Laser sonrası GiB I. saat, I. gün ve I. hafta değeri sırasıyla $A$ grubunda $12.7 \pm 3.3 \mathrm{mmHg}, 13.7 \pm 2.3 \mathrm{mmHg}, 14.2 \pm 2.3 \mathrm{mmHg}$ iken $B$ grubunda $15.1 \pm 2.9 \mathrm{mmHg}, 14.9 \pm 2.1$ $\mathrm{mmHg}, 14.5 \pm 2 \mathrm{mmHg}$ olarak ölçüldü. Laser öncesine göre laser sonrası I. saat ve I. günde $A$ grubunda anlamlı bir azalma görülürken, B grubunda laser sonrası anlamlı bir fark bulunmadı. Her iki grupta da laser sonrası I. hafta değerlerinde laser öncesine göre istatistiksel olarak anlamlı bir fark bulunmadı.

Sonuç: Çalışmamızda profilaktik brimodine kullanımının GiB artışını önlediği ancak düşük enerji ve düşük atım sayısı kullanılan ve profilksi yapılmayan GiB normal hastalarda GiB'de anlamlı bir artış olmadığı görüldü.

Anahtar Sözcükler: Brimonidine; gib; göz içi basıncı; yag laser. 